\begin{tabular}{|lll|}
\hline Diterima & $:$ & 16 Januari 2021 \\
Direvisi & $:$ & 8 Maret 2021 \\
Disetujui & $:$ & 30 Juni 2021 \\
Diterbitkan & $:$ & 30 Juni 2021 \\
\hline
\end{tabular}

\title{
DESKRIPSI REKONSTRUKSI PEMBELAJARAN ANAK USIA DINI STUDY FROM HOME PADA MASA PANDEMIK COVID-19
}

\author{
Ririn Dwi Wiresti ${ }^{1}$ \& Erni Munastiwi ${ }^{2}$ \\ email: ririnwiresti@gmail.com¹,erni.munastiwi@uin-suka.ac.id² \\ Magister Pendidikan Islam Anak Usia Dini, \\ Universitas Islam Negeri Sunan Kalijaga Yogyakarta \\ Jalan Laksda Adisucipto, Papringan, Caturtunggal, Depok, Sleman, \\ Daerah Istimewa Yogyakarta 55281, Indonesia
}

\begin{abstract}
Abstrak: Penelitian ini bertujuan untuk mendeskripsikan rekonstruksi pembelajaran anak usia dini study from home pada masa pandemik COVID-19. Pendemi ini mengakibatkan terjadinya perubahan berbagai aspek kehidupan, salah satunya aspek pendidikan. Perubahan ini menyebabkan munculnya berbagai permasalahan terkait pembelajaran, di antaranya pembelajaran yang semula tatap muka beralih menjadi belajar dari rumah. Permasalahan tersebut sebaiknya dicarikan jalan keluar, agar pembelajaran anak usia dini dapat berjalan dengan baik. Penelitian ini merupakan penelitian kualitatif dengan teknik pengumpulan data wawancara, observasi, dan dokumentasi. Partisipan penelitian adalah kepala sekolah dan wali kelas pada Kelompok Bermain TK B di TK Kreatif Primagama Yogyakarta. Pengujian keabsahan data menggunakan triangulasi sumber dan triangulasi teknik. Hasil penelitian ini menunjukkan bahwa pembelajaran anak usia dini study from home pada masa pandemik COVID-19 memengaruhi sistem pembelajaran yang ada. Oleh karena itu diperlukan rekonstruksi pembelajaran yaitu penerapan digital learning dan blended learning agar pembelajaran di masa study from home dapat berjalan lancar.
\end{abstract}

Kata-kata Kunci: digital learning, rekonstruksi pembelajaran, study from home

\section{DESCRIPTION OF THE LEARNING RECONSTRUCTION OF EARLY CHILDREN STUDY FROM HOME AT THE PANDEMIC TIME OF COVID-19}

\begin{abstract}
This study aims to describe the reconstruction of early childhood learning study from home during the COVID-19 pandemic. The COVID-19 pandemic outbreak has changed various aspects of life, one of which is education. This change has led to the emergence of various problems related to learning, including learning from face-to-face turning to learning from home. These problems should be found a way out, so that early childhood learning can run well. This study used descriptive qualitative research methods, interview data collection techniques, observation, and documentation. The participants of this study were the principal and homeroom teacher of TK B class at Primagama Creative Kindergarten Yogyakarta. The validity of the data was examined using source and technique triangulation. The results of this study indicate that early childhood learning study from home during the COVID-19 pandemic affected the existing learning system, therefore learning reconstruction is needed, namely the application of digital learning and blended learning so that learning during the study from home period can run smoothly.
\end{abstract}

Keywords: digital learning, learning reconstruction, study from home 


\section{PENDAHULUAN}

Tahun 2019 merupakan tahun bersejarah bagi dunia, karena pada akhir tahun tersebut dunia dikejutkan dengan kemunculan virus baru yaitu virus corona (COVID-19) yang diduga berasal dari Cina. Tidak kurang dari 114 negara warganya terjangkit virus ini, 1.000 orang di delapan negara telah terkonfirmasi terjangkit virus COVID-19 (Sebayang, 2020). Kejadian luar biasa ini dapat membahayakan kesehatan masyarakat dalam lingkup luas antar negara, sehingga membutuhkan respon cepat skala internasional. Untuk hal itu WHO menjadikan virus COVID-19 sebagai PHEIC atau Public Health Emergencies International Concern (Welle, 2020). Virus corona ini merupakan virus jenis baru yaitu "CO" yang pada masa awalnya disebut dengan '2019 novel coronavirus' atau '2019-nCov'. Kini virus tersebut muncul kembali dengan jenis yang mirip dengan SARS (severe acute respiratory syndrome) dan jenis flu yang lain (Unicef, 2020).

COVID-19 dapat menular jika terjadi kontak langsung antara seseorang dengan penderita. Penularan tersebut dapat terjadi melalui tetesan air liur penderita yang keluar pada saat percakapan, bersin, flu, batuk, dan bersentuhan secara langsung. Jika virus ini sudah menempel pada orang sehat, maka virus tersebut akan hidup di dalam kulit dalam rentang waktu tertentu dan jika orang tersebut kemudian menyentuh area wajah yaitu mata, hidung, dan mulut maka virus tersebut akan masuk dalam tubuh dan menyerang saluran pernafasan. Orang yang terjangkit virus corona ini akan mengalami batuk disertai sesak nafas jika dibiarkan maka akan mengalami sesak nafas hingga kejang. Hanya dalam waktu 14 hari virus ini menyerang hingga menyebabkan kematian (WHO, 2020). Maka dari itu virus corona menyebabkan krisis kesehatan masyarakat meningkat, sehingga menjadi perhatian internasional.

Adanya wabah pendemik COVID-19 yang mulai terdeteksi masuk ke Indonesia pada tanggal 2 maret 2020 membuat pembelajaran tatap muka di sekolah terhenti dan beralih menjadi belajar dari rumah. Belajar dari rumah mulai diterapkan setelah Presiden mengeluarkan kebijakan untuk bekerja dari rumah, belajar dari rumah dan beribadah dari rumah (Wiresti, 2020). Belajar dari rumah merupakan kebijakan yang diambil pemerintah untuk menimimalisir penyebaran wabah pandemik virus COVID-19 yang dapat menyebabkan terhentinya aktivitas belajar di sekolah dan proses belajar dilakukan di rumah masing-masing (Handarini \& Wulandari, 2020). Virus corona dengan cepat merebak di Indonesia, sehingga sekolah belum menyiapkan sistem pembelajaran yang cocok digunakan pada saat masa study from home.

Pada masa awal diberlakukannya study from home adanya hambatan berupa sistem pembelajaran yang belum siap, kurangnya sinergitas orang tua dengan pendidik sehingga banyak sekolah yang bingung, bahkan banyak sekolah meliburkan peserta didik (Diningrat et al., 2020). Meliburkan di sini artinya anak tidak berangkat sekolah dan tidak diberi tugas, sehingga pembelajaran terhenti. Jika hal ini terus berlanjut maka akan terjadi kesenjangan kualitas pendidikan (Vanany, 2020).

Orang tua memegang peranan penting dalam study from home, hal ini dibuktikan dengan tugas orang tua membantu serta memberikan fasilitas untuk menunjang pembelajaran (Yuliawan, 2016). Jika pendidik sudah menyiapkan pembelajaran dengan baik kemudian orang tua tidak membantu menyiapkan kebutuhan di rumah yang meliputi alat dan bahan, serta tidak mendukung dan motivasi anak untuk belajar, maka anak tidak dapat mengikuti pembelajaran dengan optimal. Study from home akan berjalan dengan optimal jika pendidik menyiapkan pembelajaran dengan baik dan orang tua memerankan perannya dengan baik. Ketika study from home diperlukan sinergi yang baik antara pendidik dan orang tua agar tujuan pembelajan tetap tercapai walaupun pembelajaran dilakukan di rumah dengan pendamping orang tua. Pendidik juga perlu memberikan edukasi kepada orang tua terkait dengan bagaimana cara mendampingi anak sesuai dengan rentang usia anak, karena cara mendampingi anak berbeda pada setiap usia. Artinya orang tua juga perlu memahami psikologi perkembangan anak karena hakikatnya anak usia dini harus bahagia (Wiresti \& Ni'mah, 2020). Ketika anak bahagia, maka otak limbiknya akan terbuka dan informasi mudah masuk dalam ingatan anak (Prima, 2018). Hal ini menunjukkan bahwa tingkat kebahagiaan anak dapat berpengaruh terhadap informasi yang masuk dalam ingatan (Porter \& Hernacki, 1999). Jadi, pada study from home, program pembelajaran harus dirancang dengan baik, sehingga anak tetap merasa bahagia dan senang ketika melakukan pembelajaran dari rumah. Aktivitas dalam study from home harus dirancang dengan aktivitas yang menarik, penuh dengan seni, serta dapat menstimulasi aspek perkembangan anak yaitu seni, kognitif, bahasa, sosial-emosional, fisikmotorik, dan nilai agama dan moral seperti aktivitas 
bermain peran. Bermain peran dalam menstimulasi berbagai aspek misalkan pada bermain peran tema profesi, anak dapat terstimulasi aspek kognitif ketika anak sedang berhitung, aspek sosial-emosioal ketika anak belajar mengontrol kesabaran, aspek bahasa ketika anak belajar berinteraksi, aspek seni ketika anak diberikan ruang untuk berekspresi (Anggraini \& Putri, 2019).

Face to face learning adalah sistem pembelajaran klasik yang digunakan mayoritas sekolah sebelum adanya wabah pandemik COVID-19 (Boughalem \& Khaldi, 2019). Sistem pembelajaran ini mengharuskan peserta didik datang langsung ke sekolah membawa buku pelajaran dan alat tulis. Namun semua itu berubah ketika adanya wabah pandemik COVID-19. Pembelajaran yang semula dilakukan di sekolah, kini setelah diberlakukannya study from home pembelajaran dilakukan di rumah masing-masing. Hal ini disebabkan karena sistem face to face learning tidak diperbolehkan pada masa pandemik.

Disusul dikeluarkannya Keputusan Menteri Pendidikan dan Kebudayaan Nomor 719/P/2020 tentang pedoman pelaksanaan kurikulum pada kondisi khusus yang sering disebut dengan kurikulum darurat (Kemendikbud, 2020). Keputusan tersebut menjawab problem pembelajaran pada masa pandemik COVID-19, di mana kepala sekolah diberikan kebebasan untuk menyusun kurikulum sendiri yang disesuaikan dengan situasi dan kondisi sekolah (Awwaliyah, 2019). Oleh karena itu kepala sekolah dan pendidik perlu membuat inovasi sistem pembelajaran yang dapat digunakan pada masa pandemik COVID-19 ini. Kepala sekolah merupakan pemegang kendali dalam melakukan inovasi (AtsTsauru \& Munastiwi, 2020). Membangun kembali dari sesuatu yang sudah ada disebut juga dengan rekonstruksi (Haryanah, 2004). Pada dasarnya sistem pembelajaran bersifat fleksibel, artinya sistem pembelajaran dapat berubah sesuai dengan situasi dan kondisi. Jadi, face to face learning pada saat ini tidak bisa diterapkan, sehingga perlu disusun dan dibangun kembali agar sesuai dengan situasi dan kondisi saat ini. Hasil penelitian (Wulandari
\& Purwanta, 2020) menunjukkan pencapaian perkembangan anak selama masa pandemik COVID-19 mengalami penurunan hampir di semua aspek. Jika kondisi ini terus berlangsung dengan intensitas yang lama, maka dikuatirkan akan terjadi los generation. Oleh karena itu, perlunya rekonstruksi pembelajaran untuk mencegah terjadinya los generation. Los generation ini terjadi akibat kurangnya akses internet dan kebutuhan gawai yang kurang memadai pda masa pandemik (Pantjoro, 2020). Los generation ditandai dengan berhentinya aktivitas belajar bagi anak (Handayani, 2004). Pembelajaran jarak jauh dinilai efektif untuk situasi pandemik saat ini bahkan negara Cina dengan ketangguhan konektivitas sukses menjalankan pembelajaran jarak jauh (World Bank, 2020). Akan tetapi di beberapa negara seperti Indonesia pada awal pandemik telah berupaya untuk melakukan Pembelajaran Jarak Jauh dengan merapel tugas dan mengirimkan via WhatsApp messenger, picture, Video call. Banyak sekolah yang ingin menggunakan Platform Google meet dan Zoom meeting namun terhambat dengan fasilitas, jaringan dan konektivitas, hanya beberapa sekolah yang dapat menggunakannya (Diningrat, Nidya \& Salwa, 2020).

Dari uraian di atas menunjukkan bahwa pentingnya rekonstruksi pembelajaran anak usia dini pada masa pandemik COVID-19. Penelitian ini membedah secara lugas, detail, dan mendalam terkait rekonstruksi pembelajaran yang dilakukan di TK Kreatif Primagama Yogyakarta. Penelitian ini bertujuan untuk memberikan gambaran dan informasi kepada stakeholder dalam dunia pendidikan terkait dengan rekonstruksi pembelajaran pada saat pandemik COVID-19. Dari hasil penelitian ini diharapkan kepala sekolah dan pendidik dapat melakukan rekonstruksi pembelajaran agar pembelajaran di masa pandemik tetap terlaksana sesuai dengan tujuan pembelajaran. Selain itu kepada orang tua dan pendidik diharapkan mampu bersinergi dengan baik untuk mendukung pembelajaran dari rumah guna menciptakan pembelajaran yang menyenangkan, sehingga anak tetap bahagia walapun pembelajaran dilakukan di rumah.

\section{METODE PENELITIAN}

Penelitian ini menggunakan pendekatan kualitatif yang bertujuan mendeskripsikan rekonstruksi pembelajaran pada anak usia dini. Data yang digunakan bersumber dari wawancara kepala sekolah dan 4 guru kelas Kelompok Bermain
(KB) TK Kreatif Primagama Yogyakarta. Selain itu juga menggunakan dokumen dan artikel ilmiah yang relevan dengan penelitian ini. Penelitian ini menggali informasi secara detail dan mendalam terkait rekonstruksi pembelajaran yang telah dilakukan 
sekolah tersebut. Teknik pengumpulan data yang digunakan : (1) Observasi yakni peneliti melakukan pengamatan secara mendalam pada proses pembelajaran yang dilakukan serta mengamati perubahan sistem pembelajarannya, (2) Wawancara yakni peneliti melakukan wawancara kepada partisipan untuk mendapatkan informasi rekonstruksi yang dilakukan sekolah guna menjaga kualitas sekolah, dan (3) dokumentasi yakni peneliti melakukan studi dokumentasi dengan merekap data yang terkait dengan rekonstruksi pembelajaran
(Sugiyono, 2015). Setelah data terkumpul, maka peneliti melakukan reduksi data untuk memilih data yang sesuai. Setelah data sesuai maka peneliti melakukan display data, dari display data tersebut peneliti melakukan penarikan kesimpulan.

Uji keabsahan data dilakukan untuk mendapatkan hasil yang kredibel. Untuk tujuan tersebut maka peneliti menggunakan uji keabsahan data triagulasi teknik dan sumber. Peneliti melakukan penelusuran dengan teknik yang sama kepada kepala sekolah dan wali kelas.

\section{HASIL DAN PEMBAHASAN}

\section{Hasil}

Temuan data yang diperoleh dari observasi, wawancara dan dokumentasi terkait dengan rekonstruksi pembelajaran anak usia dini pada masa pandemik COVID-19 menjadi fokus utama penelitian ini.

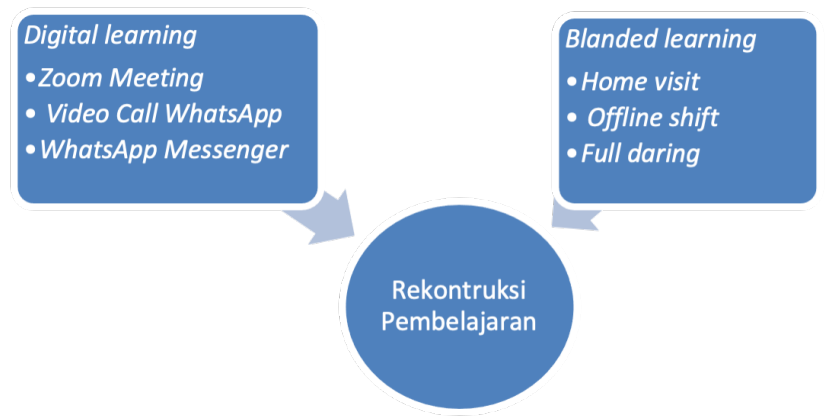

\section{Gambar 1. Rekonstruksi Pembelajaran}

Observasi dilakukan pada hari Selasa dengan tema kuman. Berikut adalah aspek yang diamati oleh peneliti.

Tabel 1.

Hasil Observasi

\begin{tabular}{ll} 
No & \multicolumn{1}{c}{ Aspek yang diamati } \\
\hline 1 & $\begin{array}{l}\text { Pendidik menyiapkan perangkat untuk memulai } \\
\text { pembelajaran secara digital }\end{array}$ \\
\hline 2 & $\begin{array}{l}\text { Anak sudah siap ketika memasuki ruang Zoom } \\
\text { meeting }\end{array}$ \\
\hline 3 & $\begin{array}{l}\text { Dalam satu hari pendidik menggunakan Zoom } \\
\text { Meeting, WhatsApp Messenger, Video Call } \\
\text { WhatsApp }\end{array}$ \\
\hline
\end{tabular}

\section{Digital Learning}

Berdasarkan wawancara, sekolah KB TK Kreatif Primagama Godean Yogyakarta melakukan rekonstruksi pembelajaran dengan menggunakan digital learning. Berikut Platform digital learning yang dipakai di sekolah :

VISI : Jurnal IImiah PTK PNF - Vol. 16 No. 1, Juni 2021
Tabel 2.

Hasil Wawancara

\begin{tabular}{ll}
\hline No & \multicolumn{1}{c}{ Platform digital learning } \\
\hline 1 & $\begin{array}{l}\text { Zoom Meeting } \\
\text { Sekolah menggunakan Platform Zoom meeting } \\
\text { supaya terjadi interaksi } 2 \text { arah antara pendidik } \\
\text { dan siswa, meningkatkan antusias belajar siswa. }\end{array}$ \\
\hline 2 & $\begin{array}{l}\text { Video Call WhatsApp } \\
\text { Sekolah menggunakan Platform Video Call } \\
\\
\text { WhatsApp supaya pendidik dan orang tua dapat } \\
\text { mengirim tugas berupa file foto, video, file tugas. }\end{array}$ \\
\hline $3 \quad$ & WhatsApp Messenger \\
& $\begin{array}{l}\text { Sekolah menggunakan Platform WhatsApp } \\
\text { Messenger supaya pendidik dapat memberikan } \\
\text { informasi terkait pembelajaran dan orang } \\
\text { tua dapat melakukan konsultasi terkait } \\
\text { perkembangan anak }\end{array}$ \\
\hline
\end{tabular}

Berdasarkan wawancara dengan wali kelas, dengan membangun kembali sistem pembelajaran tatap muka (face to face learning) menjadi digital learning, maka sekolah TK Primagama tidak mengalami penurunan hasil belajar hal ini dapat dibuktikan dengan meningkatnya capaian perkembangan anak didik.

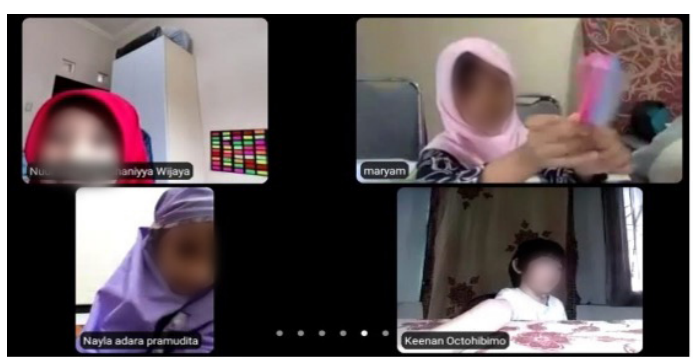

Gambar 2. Ruang Zoom Meeting

Bahkan antusias belajar antar anak semakin meningkat dan orang tua terus memotivasi anak untuk mengembangkan pengetahuannya sehingga hasil belajar pada saat pandemik cenderung meningkat. Sinergi yang baik antara orang tua dan pendidik menjadi dasar utama digital learning dalam dunia pendidikan anak usia dini. 


\section{Blended Learning}

Sistem pembelajaran yang semula hanya menggunakan face to face learning kini berubah menjadi blended learning. Pembelajaran campuran atau blended learning merupakan paduan antara pembelajaran tatap muka dengan pembelajaran digital atau e-learning (Putra, dkk., 2019). Hasil wawancara dengan kepala sekolah KB TK Kreatif Primagama Yogyakarta menggunakan sistem blended learning di masa pandemik yang disebut dengan program "mixing daring".

Dalam mixing daring ini sekolah menyediakan pilihan pembelajaran campuran. Berikut adalah pilihan yang ditawarkan sekolah kepada orang tua untuk pembelajaran saat pandemik :

Tabel 3.

Jenis Mixing Daring

\begin{tabular}{|c|c|}
\hline No & Jenis Mixing Daring dan Ketentuan \\
\hline 1 & $\begin{array}{l}\text { Homevisit } \\
\text { homevisit dilakukan satu kali dalam satu minggu } \\
(1 \times \text { seminggu), pembelajaran melalui zoom } \\
\text { meeting dua kali seminggu ( } 2 \text { x seminggu), dan } \\
\text { mengikuti kegiatan belajar mengajar pasif dua } \\
\text { kali seminggu ( } 2 \text { x seminggu). }\end{array}$ \\
\hline 2 & $\begin{array}{l}\text { Offline Shift } \\
\text { dua kali seminggu ( } 2 \text { x seminggu), kegiatan } \\
\text { belajar mengajar pasif dua minggu sekali ( } 2 \\
\text { x seminggu) pada KBM pasif ini orang tua } \\
\text { mendapat kiriman daftar fokus tema yang } \\
\text { dilakukan di hari tersebut, dan zoom meeting } \\
\text { seminggu sekali ( } 1 \text { x seminggu). }\end{array}$ \\
\hline 3 & $\begin{array}{l}\text { Full Daring } \\
\text { orangtua tidak memilih homevisit dan offline shift. } \\
\text { Full daring ini murni dengan zoom meeting tiga } \\
\text { kali dalam seminggu ( } 3 \text { x seminggu), ditambah } \\
\text { dengan kegiatan belajar mengajar pasif satu } \\
\text { minggu sekali ( } 1 \text { x seminggu) pada KBM pasif } \\
\text { pendidik mengirimkan fokus tema dan daftar apa } \\
\text { saja yang dilakukan hari itu. }\end{array}$ \\
\hline
\end{tabular}

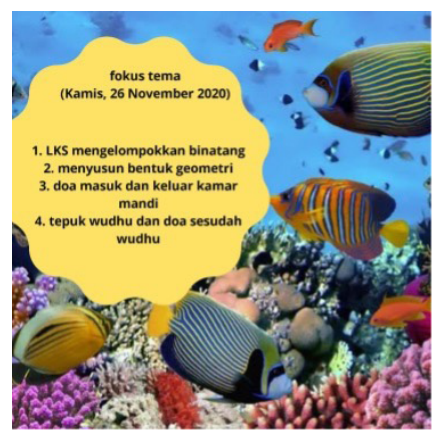

Gambar 3. Daftar Tugas dan Fokus Tema

Dari ketiga sistem pembelajaran campuran tersebut, sekolah memberi kebebasan kepada orang tua untuk memilih sistem pembelajaran yang sesuai dengan keinginan dan kebutuhan orang tua. Pihak sekolah siap melayani peserta didik pada ketiga sistem pembelajaran campuran tersebut.

\section{Pembahasan}

Berdasarkan hasil penelitian melalui teknik observasi, wawancara, dan dokumentasi, diperoleh beberapa informasi. Pertama, sekolah melakukan rekonstruksi pembelajaran dari yang semula pembelajaran tatap muka menjadi pembelajaran berbasis digital memang tidak semudah yang dibayangkan. Hal ini didukung oleh penelitian (Akrim, 2018) yang mengungkapkan bahwa waktu sangat dibutuhkan untuk beradaptasi dengan berbagai platform digital yang akan digunakan sebagai sarana belajar.

Digital learning akan menjadi jawaban atas merebaknya wabah pandemik yang sampai saat ini masih terjadi. Bahkan digital learning menjadi sebuah kehidupan baru bagi dunia pendidikan. Metode sebuah proses belajar-mengajar, tetapi juga berkaitan dengan bagaimana cara untuk meningkatkan peran guru dari penanaman pengetahuan yang diterima (Faustmann, et.al., 2019). Menjadikan pendidik sebagai rekan pencipta sebuah pengetahuan, pelatih, mentor, dan evaluator. Pada masa pandemik teknologi menjadi sebuah hal yang penting, bahkan kekurangan teknologi digital dapat memengaruhi tingkat kualitas pembelajaran. Hal ini disebabkan karena teknologi digital menjadi media sarana utama penunjang pembelajaran. Maka jika teknologi digitalnya kurang maka akan menghambat pembelajaran. Berdasarkan survei Internasional Pengajaran dan Pembelajaran OECD (TALIS) pada tahun 2018 rerata hanya 53\% guru yang mengizinkan siswanya untuk menggunakan informasi dan komunikasi (Schleicher, 2020). Data tersebut menunjukkan bahwa $47 \%$ guru tidak mengizinkan muridnya untuk menggunakan informasi dan komunikasi, padahal wabah pandemik COVID-19 telah merubah sistem pendidikan yang ada. Berikut adalah persentase guru yang sering atau selalu mengizinkan siswa mengakses teknologi informasi dan komunikasi :

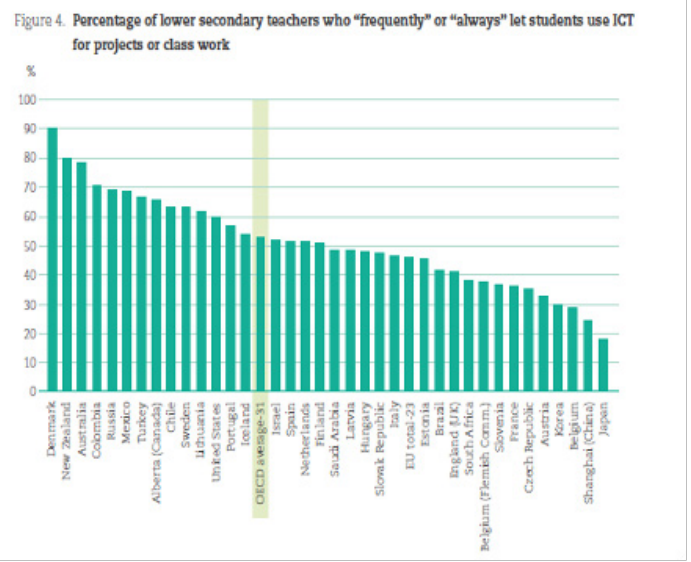

Gambar 1.2. Persentase guru mengizinkan siswa untuk mengakses TIK 
Ketika guru membiasakan siswa untuk mengakses internet maka pada sistem pembelajaran yang berbasis digital seperti saat ini, siswa tidak kaget karena sudah terbiasa. Akan tetapi jika belum terbiasa atau bahkan belum pernah, maka akan kaget dan membutuhkan waktu untuk memahami dan menggunakan.

Semua platform digital menggunakan akses internet maka sinyal atau jaringan menjadi sebuah hal yang penting. Bahkan dapat dikatakan sinyal adalah jantung bagi pembelajaran digital sebab jika tidak ada sinyal maka pembelajaran yang berbasis digital tidak dapat terlaksana. Guna mendukung digital learning sekolah KB TK Kreatif Primagama berlangganan internet (WIFI) dan berlangganan Zoom Meeting.

Pada penelitian ini sekolah menggunakan platform digital zoom meeting karena pada platform tersebut interaksi antara pendidik dan peserta didik dapat terjalin secara langsung seperti pada pembelajaran tatap muka (interaksi 2 arah), pendidik dapat secara langsung mengetahui hasil belajar anak, pendidik tetap dapat mengamati apa yang dilakukan peserta didik. Zoom meeting masuk dalam kategori synchoronous karena pembelajaran dapat dilakukan secara langsung, dalam satu waktu, dan interaktif (Fahmi, 2020). Pendidik harus bersinergi dengan orang tua, berikut bentuk sinergi antara pendidik dan orang tua :

1. Pendidik menyiapkan alat, bahan, dan lembar kerja peserta didik selama satu minggu ke depan. Alat, bahan, dan lembar kerja disatukan dalam map yang akan diberikan pada orang tua.

2. Orang tua menerima map yang berisi alat, bahan, dan lembar kerja yang akan digunakan pada saat pembelajaran.

3. Lima belas menit sebelum pembelajaran dilakukan, orang tua menyiapkan alat dan bahan yang akan diperlukan.

4. Pada saat pembelajaran orang tua mendampingi anaknya, pada saat ini orang tua bertugas mengontrol anak agar dapat mengikuti pembelajaran dengan baik.

5. Pada saat selesai pembelajaran orang tua melakukan recalling terhadap anak, hal ini bertujuan agar anak ingat apa yang tadi diajarkan oleh bunda guru pada saat online class.

Selain platform zoom meeting, sekolah juga menggunakan platform whatsApp. Aplikasi whatsApp masuk dalam kategori synchronous ketika yang digunakan adalah video call, karena dengan video call komunikasi dapat terjalin secara 2 arah dan interaktif dalam satu waktu dan dapat bertatap muka. Sedangkan Aplikasi whatsApp masuk dalam kategori asynchronous ketika komunikasi yang terjalin hanya 1 arah dan tidak dalam satu waktu yaitu whatsApp massenger yang berupa foto, video, voice note, dan pesan.

Digital learning merupakan sistem pembelajaran yang efektif pada masa study from home. Hal ini sejalan dengan penelitian Lin, Chen, \& Liu (2017) yaitu digital learning sebagai sistem pembelajaran yang efektif yang dapat memotivasi anak untuk belajar dan memberikan dampak positif bagi hasil belajar anak. Peningkatan hasil pencapaian belajar anak pada masa study from home di pengaruhi oleh beberapa faktor antara lain seperti paragraf di bawah ini.

Pada masa new normal pembelajaran masih study from home, artinya beberapa orang tua sudah mulai berangkat bekerja sedangkan anak masih belajar di rumah. Tidak semua orang tua bisa mendampingi belajar anak di rumah, karena kesibukan setiap orang tua berbeda-beda (Wulandari \& Purwanta, 2020).

Kedua, sistem blended learning merupakan sebuah hasil rekonstruksi dari face to face learning. Blended learning adalah pembelajaran campuran antara tatap muka secara langsung yang biasa disebut sebagai synchronous dan pembelajaran yang dilakukan secara digital tetapi tidak dalam satu waktu yang biasa disebut dengan asynchronous (Wardani, dkk., 2018).

Pembelajaran synchronous memungkinkan pendidik untuk mengajar sebagai mana pendidik mengajar di kelas, hal ini disebabkan karena dalam pembelajaran synchronous pendidik dan anak didik bertemu dalam satu waktu sehingga dapat terjadi interaksi dua arah. Sedangkan dalam pembelajaran asynchronous pendidik dan anak didik berinteraksi dalam satu waktu sehingga interaksi hanya terjadi secara satu arah (Rausch \& Levi, 1996).

Tumpuan utama tingkat keberhasilan pada blended learning terletak pada profesionalitas pendidiknya (Lim \& Wang, 2017). Tanpa pendidik yang kompeten dan mampu mengoperasionalkan teknologi, maka sistem blended learning tidak akan mencapai tujuan pembelajaran secara optimal. Semua harus terintegrasi. Pendidik yang mampu dan menguasai bidangnya akan tetapi ia kurang mengikuti perkembangan teknologi, maka sistem blended learning tidak dapat berjalan dengan optimal. Sebaliknya jika pendidik menguasai teknologi, akan tetapi tidak mengetahui bidang apa yang diajarkan, maka blended learning juga tidak dapat berjalan dengan optimal. Peran pendidik dalam aktivitas pembelajaran 
antara lain sebagai: (1) motivator, di mana peran guru adalah memotivasi anak didik yang kurang semangat dalam mengerjakan sebuah aktivitas. Hal ini dilakukan agar anak menjadi semangat, riang, dan gembira untuk melakukan sebuah aktivitas; (2) Pengajar, di mana pendidik sebagai pengajar mempunyai tugas untuk menstranfer ilmu ke anak didik dan membangun pengetahuan; (3) Penasihat, di mana pendidik sebagai penasihat mempunyai tugas memberi pesan kepada anak didik agar anak didik menjadi anak yang baik; (4) Role model, di mana pendidik mempunyai tugas untuk selalu bertingkah laku yang baik karena perilakunya akan dicontoh oleh anak didik; (5) Pembimbing di mana pendidik mempunyai tugas membimbing anak dalam pengetahuan, karakter, dan keterampilan hidup; (6) Pelatih, di mana pendidik sebagai pelatih mempunyai tugas untuk memberikan pembelajaran yang dapat menstimulasi aspek perkembangan kognitif, seni, bahasa, nilai agama dan moral, fisikmotorik, dan sosial-emosional; (7) Pemberi teladan. di mana pendidik sebagai pemberi teladan mempunyai tugas memberi contoh yang baik kepada anak didik, dan (8) Pengevaluasi, di mana pendidik berperan sebagai pengevaluasi atau penilai mempunyai tugas untuk menilai hasil belajar anak dan menilai seberapa jauh capaian perkembangan anak didik (Taher \& Munastiwi, 2019).

Selain itu orang tua juga turut berperan atas keberhasilan blended learning pada tingkat anak usia dini. Dalam hal ini orang tua juga dapat dikatakan menjadi kunci penentu keberhasilan study from home (Umar, 2015). Orang tua berperan untuk menyiapkan sebuah kondisi lingkungan yang kondusif untuk anak usia dini. Hal tersebut dilakukan untuk menciptakan suasana belajar yang nyaman dan aman sehingga dalam mengikuti pembelajaran anak bisa fokus dan memperoleh hasil yang maksimal (Huda \& Munastiwi, 2020). Pada usia tersebut anak masih memerlukan pendamping untuk menyiapkan alat, bahan dan lembar kerja sesuai dengan arahan pendidik.

\section{PENUTUP}

Dari hasil penelitian ini dapat disimpulkan bahwa pada masa pandemik COVID-19 diperlukan rekonstruksi pembelajaran, hal ini disebabkan karena face to face learning tidak dapat diterapkan sedangkan pembelajaran harus tetap berlangsung. Digital learning dan Blended learning merupakan sebuah hasil rekonstruksi pembelajaran yang efektif dan efisien pada masa study from home. Digital learning adalah platform yang digunakan sebagai media pembelajaran online yaitu Platform Zoom meeting, Video Call WhatsApp, dan WhatsApp Messenger. Sedangkan Blended Learning di sekolah KB TK Kreatif Primagama Godean adalah perpaduan antara platform yang digunakan dengan nama program "mixing daring". Mixing daring terbagi menjadi 3 yaitu : (1) Home visit, (2) Offline shift, (3) Full daring.

Saran berdasarkan hasil penelitian ini adalah bagi pendidik diharapkan terus mengembangkan sistem pembelajaran yang ada agar lebih menarik, sehingga bisa berkontribusi dalam keilmuan PAUD. Bagi kepala sekolah diharapkan agar terus memfasilitasi kebutuhan pendidik untuk mengembangkan sistem pembelajaran. Bagi orang tua diharapkan agar terus memotivasi anak agar semangat mengikuti pembelajaran di masa pandemik.

\section{DAFTAR PUSTAKA}

Akrim, M. (2018). Media learning in digital era. Proceedings on 5th International Conference on Community Development (AMCA 2018). Advances in Social Science, Education and Humanities Research, 231, 458-460. DOI: 10.2991/amca-18.2018.127

Anggraini, W., \& Putri, A. D. (2019). Penerapan Metode Bermain Peran (Role Playing) dalam Mengembangkan Kognitif Anak Usia 5-6 Tahun. JECED : Journal of Early Childhood Education and Development, 1 (2), 104-114. DOI: 10.15642/jeced.v1i2.466

Ats-Tsauru, M. S., \& Munastiwi, E. (2020). Strategi Kepala Madrasah Dalam Menentukan Kebijakan
Pembelajaran Era Covid-19: Studi Kasus Kepala Madrasah Ibtidaiyah NW Pondok Gedang. Elementerls : Jurnal IImiah Pendidikan Dasar Islam, 2 (2), 55-61. DOI: 10.33474/ elementeris.v2i2.8679

Awwaliyah, R. (2019). Pendekatan Pengelolaan Kurikulum Dalam Menciptakan Sekolah Unggul. INSANIA : Jurnal Pemikiran Alternatif Kependidikan, 24 (1), 35-52. DOI: 10.24090/ insania.v24i1.2219

Boughalem, M. A., \& Khaldi, M. (2019). Social Constructivism and Digital Learning. International Journal of Smart Education and Urban Society (IJSEUS), 10 (3), 13-22. DOI: 
10.4018/IJSEUS.2019070102

DePorter, B. \& Hernacki, M. (1999). Quantum Learning: Membiasakan Belajar Nyaman dan Menyenangkan. Bandung: Kaifa.

Diningrat, S. W. M., Nindya, M. A., \& Salwa, S. (2020). Emergency Online Teaching: Early Childhood Education Lecturers' Perception of Barrier and Pedagogical Competency. Jurnal Cakrawala Pendidikan, 39 (3), 705-719. DOI: 10.21831/ cp.v39i3.32304

Fahmi, M. H. (2020). Komunikasi Synchronous dan Asynchronous dalam E-Learning pada Masa Pandemik COVID-19. Jurnal Nomosleca, 6 (2), 146-158. DOI: 10.26905/nomosleca.v6i2.4947

Faustmann, G., Kirchner, K., Lemke, C., \& Monet, D. (2019). Which factors make digital learning platforms successful. Proceedings of The 13th Annual International Technology, Education and Development Conference. DOI: 10.21125/ inted.2019.1651

Handarini, O. I., \& Wulandari, S. S. (2020). Pembelajaran Daring Sebagai Upaya Study From Home (SFH) Selama Pandemi Covid 19. Jurnal Pendidikan Administrasi Perkantoran (JPAP), 8 (3), 496503. Retrieved from https://journal.unesa.ac.id/ index.php/jpap/article/view/8503/4094

Handayani, A. S. (2004). The lost generation phenomena in the early 20 th century as seen through $f$. scott fitzgerald' $s$ this side of paradise. Tesis tidak diterbitkan. Surakarta: Universitas Sebelas Maret.

Haryanah, N. (2004). Rekonstruksi Sistem Pendidikan Di Indonesia Sebagai Upaya Meningkatkan Kualitas Bangsa. Mimbar: Jurnal Sosial dan Pembangunan, 20 (4), 540-554. DOI: 10.29313/ mimbar.v20i4.157

Huda, K., \& Munastiwi, E. (2020). Strategi Orang Tua Dalam Mengembangkan Bakat Dan Kreativitas Di Era Pandemi Covid-19. Jurnal Pendidikan Glasser, 4 (2), 80-87. DOI: 10.32529/glasser. v4i 2.670

Kemendikbud. (2020). Salinan Keputusan Menteri Pendidikan dan Kebudayaan Nomor 719 IPI2O2O. Jakarta: Kemendikbud

Lim, C.P. \& Wang, L.B. (Eds.) (2017). Blended Learning for Quality Higher Education: Selected Case Studies on Implementation from Asia-Pacific. Paris, France: UNESCO.

Lin, M. H., Chen, H. C., \& Liu, K. S. (2017). A study of the effects of digital learning on learning motivation and learning outcome. Eurasia Journal of Mathematics, Science and
Technology Education, 13 (7), 3553-3564.DOI: 10.12973/eurasia.2017.00744a

Pantjoro, T. (2020). Potensi Lost Generation Akibat Pandemi Covid-19. Ybb.or.id. Retrieved from https://www.ybb.or.id/potensi-lost-generation/

Prima, E. (2018). Pengaruh Ritme Otak dan Musik dalam Proses Belajar. Komunika: Jurnal Dakwah dan Komunikasi, 12 (1), 43-57. DOI: 10.24090/komunika.v12i1.1351

Putra, A.B.N.R.P., Zahro, A. H., Mukhadis, A., Ulfatin, N. \& Ashar, M. (2019). Learning Innovation Online Course Based on Blended Learning for Interactive Learning in The Era of Education 4.0. Jodli: Journal of Disruptive Learning Innovation, 1 (1), 47-56. DOI: 10.2021/jodli.v1i1.9788

Rausch W.A. \& Levi P. (1996). Asynchronous and Synchronous Cooperation. Dalam Asama $\mathrm{H}_{\text {., }}$ Fukuda T., Arai T., Endo I. (eds.) Distributed Autonomous Robotic Systems 2. Tokyo: Springer. DOI: 10.1007/978-4-431-66942-5_22

Schleicher, A. (2020). The impact of COVID-19 on education: Insights from education at a glance 2020. OECD Journal: Economic Studies. Retrieved from https://www.oecd.org/education/ the-impact-of-covid-19-on-education-insightseducation-at-a-glance-2020.pdf

Sebayang, R. (2020). Alert! WHO Resmi Tetapkan Corona Pandemi. CNBC Indonesia.com. Diakses dari https://www.cnbcindonesia.com/ news/20200312064200-4-144245/alert-whoresmi-tetapkan-corona-pandemi pada 25 Juni 2021

Sugiyono. (2015). Cara Mudah Menyusun Skripsi, Tesis, dan Disertasi. Edisi 1 Cetakan 3. Bandung: Alfabeta.

Taher, S. M., \& Munastiwi, E. (2019). Peran Guru Dalam Mengembangkan Kreativitas Anak Usia Dini Di TK Islam Terpadu Salsabila Al- Muthi'in Yogyakarta. Golden Age: Jurnal IImiah Tumbuh Kembang Anak Usia Dini, (2), 35-50. DOI: 10.14421/jga.2019.42-04

Umar, M. (2015). Peranan Orang Tua Dalam Peningkatan Prestasi Belajar Anak. Jurnal Edukasi: Media Kajian Bimbingan Konseling, 1 (1), 20-28. DOI: 10.22373/je.v1i1.315

Unicef. (2020). Key Messages and Actions for Prevention and Control in Schools. New York: Unicef

Vanany, I. (2020). Akankah Terjadi Lost Generation karena Pandemi Covid-19? Radar Surabaya. Id Diakses dari https://radarsurabaya.jawapos. com/read/2020/08/07/207906/akankah-terjadi- 
lost-generation-karena-pandemi-covid-19 pada tanggal 25 Juni 2021

Wardani, D. N., Toenlioe, A. J. E., \& Wedi, A. (2018). Daya Tarik Pembelajaran Di Era 21 Dengan Blended Learning. Jurnal Kajian Teknologi Pendidikan (JKTP), 1 (1), 13-18. Retrieved from http://journal2.um.ac.id/index.php/jktp/article/ view/2852

Welle, D. (2020). WHO Umumkan Situasi Darurat Global Terkait Virus Corona, Apa Artinya? detik.com. Diakses dari https://news.detik.com/ dw/d-4881787/who-umumkan-situasi-daruratglobal-terkait-virus-corona-apa-artinya pada 25 Juni 2021

WHO. (2020). Transmisi SARS-CoV-2 : implikasi terhadap kewaspadaan pencegahan infeksi. Pernyataan Keilmuan. Diakses dari https://www. who.int/docs/default-source/searo/indonesia/ covid19/transmisi-sars-cov-2---implikasi-untukterhadap-kewaspadaan-pencegahan-infeksi--pernyataan-keilmuan.pdf?sfvrsn=1534d7df_4

Wiresti, R. D. (2020). Analisis Dampak Work From Home pada Anak Usia Dini di Masa Pandemi Covid-19.
Jurnal Obsesi : Jurnal Pendidikan Anak Usia Dini, 5(1), 641. https://doi.org/10.31004/obsesi. v5i1.563

Wiresti, R. D. \& N'imah (2020). Aspek Perkembangan Anak: Urgensitas Ditinjau dalam Paradigma Psikologi Perkembangan Anak. Aulad: Journal on Early Childhood, 3 (1), 36-44. DOI: 10.31004/ aulad.v3i1.53

World Bank. (2020). Guidance Note on Education Systems' Response to COVID19 How does COVID19 impact education? Retrieved from https://www.cdc.gov/coronavirus/2019-ncov/ downloads/considerations-for-school-closure. pdf

Wulandari, H., \& Purwanta, E. (2020). Pencapaian Perkembangan Anak Usia Dini di Taman Kanak-kanak selama Pembelajaran Daring di Masa Pandemi Covid-19. Jurnal Obsesi : Jurnal Pendidikan Anak Usia Dini, 5 (1), 452. DOI: 10.31004/obsesi.v5i1.626

Yuliawan, T. P. (2016). Coaching Psychology: sebuah Pengantar. Buletin Psikologi, 19 (2), 45-54. DOI: 10.22146/bpsi.11556 
56 VISI : Jurnal IImiah PTK PNF - Vol. 16 No. 1, Juni 2021 